\title{
Corporate Governance Development and Practices in an Emerging Economy: A Review of Empirical Findings and Literature in Saudi Arabia
}

\author{
Bader Alharbi ${ }^{1} \&$ Abdullah Alharbi ${ }^{1}$ \\ ${ }^{1}$ Ministry of Education, The Kingdom of Saudi Arabia \\ Correspondence: Bader Alharbi, Ministry of Education, The Kingdom of Saudi Arabia. E-mail: \\ Alharbi.bader.au@gmail.com
}

Received: December 4, 2020

Accepted: January 19, 2021

Online Published: February 3, 2021

doi:10.5539/ijbm.v16n3p11

URL: https://doi.org/10.5539/ijbm.v16n3p11

\begin{abstract}
Purpose: The aim is to review the literature and present some of the academic contributions researchers have made in the study, development and practice of corporate governance (CG) in Saudi Arabia.

Design/Methodology: We conducted a guided words search on electronic databases using "corporate governance in Saudi Arabia" as the search words. The scope of the study was restricted to the needed materials and information contained in refereed journals from 1965 to 2018 and held in the ABI/INFORM Global, Emerald databases and a few other internationally recognized electronic databases. The papers were first sorted into areas of possible CG application. They are finally analyzed and then synthesized.

Findings: That six broad areas have been examined in relation to CG structures and development; they include: company financial performance, corporate social responsibilities, earnings management, corporate voluntary disclosures, financial structure and the role of $\mathrm{CG}$ in times of financial crisis. The papers are skewed in favour of, CG and company financial performance at the expense of other areas. CG has evolved, even though, the country's institutional environment may not be too close to those of OECD nations, but the establishment of the new 2006 CG code is a positive addition to the business culture. Nevertheless, there are still other outstanding CG issues identified by scholars and practitioners that are not in conformity with international best CG practices.
\end{abstract}

Research limitations/implications: The study's analysis was restricted to between 1965 and 2018, and papers from some and not all electronic data bases were used.

Originality/value: The paper provides a comprehensive review and analysis CG development and practice in an emerging economy where greater importance is usually attached to informal relationships and other considerations than formal CG mechanisms.

Keywords: Corporate governance, corporate governance code, corporate governance development, board of directors, Saudi Arabia

\section{Introduction}

This study is to review the literature and present some of the academic contributions researchers have made in the study and development of CG in Saudi Arabia. It is done through the articulation of ideas drawn from their published works. Previous studies on CG in Saudi Arabia have mainly concentrated on CG and company financial performance only. But this paper attempts a comprehensive reviewed of literature on CG in several other areas (company financial performance, corporate social responsibilities, earnings management, voluntary disclosures, financial structure and even the role of $\mathrm{CG}$ in times of financial crisis) of the Saudi Arabian economy.

Corporate governance evolved as a result of economic and sometimes political necessity; to partially address the concerns of the public with regards to persistent corporate failures and attempt to restore investors and public confidence. According to Mason et al. (2007, p. 287) "High-profile mismanagement of large multi-national private-sector corporations have brought heightened media attention to the whole issue of corporate governance". Academics are not also left out in the call for a review and development of sound CG system to help monitor and control the excesses of corporate managers (Darus, 2011; Stein, 2008; Merino et al., 2010). Darus, (2011, p. 125) 
emphasized that; "corporate governance problems arise due to the misalignment of interests between managers and investors because of the separation of ownership and control in a company".

This research provides a comprehensive review and analysis CG development and practice in an emerging economy. The outcome of the review shows that the CG framework and structures which relies on the principles of responsibility, fairness, transparency and accountability are deficient and inadequate in Saudi Arabia. CG is basically concerned with good management of public companies and by extension the protection of share/stakeholders' interest. The CG structures are to align shareholders and management interests thereby reducing agency costs.

Evidence of study on CG mechanisms and policies is extensive and cutting across geographical settings, practices, and possibly legal environment and possible corporate governance. But $\mathrm{n}$ doing so, Scholars should recognize and acknowledge the context (e.g. cultural, religious etc.) of each nation before evaluating the success or failure of CG practices. Corporate managers should also note that a company's CG structures and practices are value relevant information that is being considered by equity market participants in making investment decisions.

The paper is set out as follows: Section 2 gives a general overview and some of the paradigms (agency, stakeholders and stewardship theories) of corporate governance. Section 3 is on CG development in Saudi Arabia. Section 4 examines the Saudi CG regulations of 2006 and as amended. Section 5 is the critical review of literature and findings on CG structures in Saudi Arabia. Section 6 is the methodology adopted. Finally: the conclusion is presented in section 7 .

\section{Corporate governance}

There are several perspectives and definitions of CG. For example, the agency framework considers CG as a system constituted by equity or shareholders to maximize returns on their investments, with the intention to monitor and control their agents or the corporate managers (Short et al., 1999; Cohen et al., 2002; Darus, 2011; Adegbite et al. 2012). Cohen et al. (2004, p. 88) colourfully describe these mechanisms as the "corporate governance mosaic". Their main purpose is to align shareholders and management interests thereby reducing agency costs.

CG could also be viewed from stakeholders' theory perspective. The central idea of this theory according to Hill and Jones (1992, p. 134), is that "whatever the magnitude of their stake, each stakeholder is a part of the nexus of implicit and explicit contracts that constitutes the firm". This theory place more attention on governing boards of corporation and their duties not only to their employees and equity holders who are their primary stakeholders, but also to their other external stakeholders (Donaldson and Preston, 1995; Hung, 1998). Therefore, CG primary purpose is providing a "vehicle for coordinating stakeholder interests" Evan and Freeman, (1988, cited in Donaldson and Preston, 1995, p. 74). The ultimate aim is to reduce or possibly eliminate the effects of information asymmetry, by creating structures where all stakeholders can express their views and protect their rights (Bonnafous-Boucher, 2005).

On the other hand, Stewardship theory argue that the primary purpose of CG is to "focus not on motivation of the CEO but rather facilitative, empowering structures that will enhance effectiveness and produce a result; superior returns to shareholders" (Donaldson and Davis, 1991, p. 52). The focus is on "structures that facilitate and empower rather than those that monitor and control" (Davis et al., 1997, p. 25).

Beside the above views, there are several other definitions and perspectives of what CG is or what it should be. Sternberg (1998, p. 20) state that the fundamental role of CG is "ensuring that corporate actions, assets and agents are directed at achieving the corporate objectives established by the corporation's shareholders". The central theme in all these theories is the management of the relationship between the principal or the financial supplier and the agent or corporate manager, and how to protect the interest of the former to avoid conflict of interests. Therefore, it could be rightly assumed that CG from the perspective of agency theory refers to policing or control methods employed by the providers of capital to keep agents who are the corporate managers in check in other to protect their interest or investment in the corporation.

OECD (1999) gave a broader definition; "Corporate governance is the system by which business corporations are directed and controlled. The corporate governance structure specifies the distribution of rights and responsibilities among different participants in the corporation, such as, the board, managers, shareholders and other stakeholders, and spells out the rules and procedures for making decisions on corporate affairs. By doing this, it also provides the structure through which the company objectives are set, and the means of attaining those objectives and monitoring" A classical definition by Shleifer and Vishny (1997) sees CG as a method of securing return on their investment by corporation's financial suppliers. Gillibrand (2004) definition of CG is centered on 
structures, procedures and rules that enable corporate decisions making through which the objectives of the firm can be monitored and achieved.

Furthermore, O'Donovan (2003, cited in Man, 2013, p. 391) sees "corporate governance as an internal system that includes processes, policies and people that serve the requirements of shareholders as well as other stakeholders by controlling and directing activities by the firm's management with good business objectivity and integrity". Classens (2003), tried to sum up the various definitions of CG and their emphasis. He concluded that all the definitions fall into two broad groups namely; behavioral pattern sets which include the corporation's actual behaviour, this consists among others; the way the corporation treat its stake holders both internal and external, financial structure, utilization of its assets and liabilities and growth pattern. The second set of definitions he argued are normative in nature as they are focused mainly on rules and regulations governing the operations of companies such as the legal and judicial system, the labour and financial markets.

The various views and definitions mentioned above are by no means exhaustive. "As there is a significant divergence of opinion as to the meaning of corporate governance within each tradition, perspectives and theoretical viewpoints" (L' Huillier, 2014, p.316). According to Stiles (1997) of the London Business School (cited in L' Huillier, 2014, p. 3) "It would appear that no general theory of corporate governance exists, and that it is a contested concept with different meanings for different people depending on their ontological preferences".

\section{CG Development in Saudi Arabia}

Saud Arabia has witnessed several CG reforms in one form or the other, starting from the company law of 1965 to the Saudi's Corporate Governance Regulations of 2006 that was subsequently amended in April, 2018. But the question is how are these CG reforms compared to OECD standards? The issue of comparism and standard has lead to further questions. Indeed, the measurement of standard has also lead to some researchers to debate on the Western style of CG to compare with those of emerging markets (Wright et al., 2005). La Porta et al. (1999) argued that the context on which issues are debated must consider the national context and cultural perceptions, and therefore what constitutes quality governance mechanisms can vary considerably between developed and emerging markets. One may therefore, consider CG development in the context of the above views in respect of Saudi Arabia.

The story of development of CG in Saudi could indeed be traced to 1965 with the beginning of the Companies Law. This Law governs the establishment and operations of both private and public companies. Furthermore, internal control standards were also set in 2000 . Under these standards, companies operating in the country should design their internal control system (Meteb, 2015). Subsequently the Saudi Corporate Governance Regulations or codes was first introduced by The Capital Market Authority (CMA) in 2006 to provide a universal guideline of rules and regulations for companies listed on the Saudi Arabia stock exchange and also to protect investors' rights.

Observers of Saud Arabia's CG system believe to some extent that the country has made relative progress especially in CG structures with cultural colorations that support the human resource management function (Robertson et al. 2012). This progress as promising as it may be cannot stand the test of time when compared with Western governance standards, as some components of a comprehensive governance strategy have not been fully integrated into the Saudi governance system. Specifically the audit functions and the respective committees are yet to be fully integrated into the system in many Saudi Arabia companies (Al-Twaijry et al., 2002).

The Saudi Stock Market under the supervision of CMA has also introduced and implemented some policies and best practices that may protect shareholders, especially minority shareholders. This is evidenced partly in the gradual increase in the market value of shares in the Saudi Stock Market. Unfortunately, this positive trend was disrupted in the beginning of 2006 when the market failed, resulting enormous loss to investors especially minority shareholders (Alshehri, 2012; Hill et al., 2015). Which financial observers, believed was as a consequence of lack of effective CG mechanisms and market infractions. This incident among others prompted the CMA to approve new regulations for CG to protect shareholders and other stakeholders (Al Mulhim, 2014; Hill et al., 2015). Prior to 2006, there were no precise regulations or CG codes in Saudi Arabia (Al Mulhim, 2014). How effective is the 2006 code and its subsequent amendments?

The effectiveness of some of the CG structures in the Kingdom is inadequate, so also is the CG framework which relies on the principles of responsibility, fairness, transparency and accountability very weak. There are specific challenges militating against these tested principles of CG in the context of Saudi Arabia. Principal among such factors is the corporate ownership structure. Saudi Arabia has concentrated shares ownership structures, majority of corporate shares are owned by a controlling block, which is owned by members of the 
same family in most cases.

According to Saidi, (2004) in the Kingdom, the majority shareholders are also usually the company owners because most listed companies began as family businesses and later became public companies. Families, directly or indirectly, own a very high percentage of equity shares of all companies and keep the majority control. Therefore, the executive directors, even including the independent directors are usually members of the same family or lineage. Under this scenario, two of the most important CG variables; ownership and board structures that directly affect nominations and appointments into committees have been compromised and so also is the level of control over management. Yasin and Shehab (2004) concluded that the high concentration in corporate ownership undermines the principles of good CG in most developing economies and this is especially so in Saudi Arabia.

From an agency perspective the board of directors is seen as a disciplining mechanism on the discretionary behavior of managers, but when the board's composition and size seem to be related to the alignment of managers (family members), corporate strategies including monitoring strategies tend to take second place. The 'independent directors' may no longer be independent, so also is the independence of the audit committee in performing their statutory corporate functions. According to Mujtaba and William, (2011) the lack of a clear definition of independent directors in the various corporate governance codes and guidelines issued by regulatory authorities in the GCC region might prevent companies from appointing 'truly' independent directors.

When tested CG controls are not functioning effectively corporate managers' opportunistic behaviour expressed in the form of earnings management and any other selfish interest of managers may not be sufficiently controlled. Therefore, it is not only the existence of the law (regulations or codes) but its implementation to achieve the purpose of the law.

Several studies (Al-Ghamdi \& Rhodes, 2015; Al-Matari et al., 2012; Fallatah \& Dickins, 2012) have examined the current CG system in Saudi Arabia and are of the view that it does not motivate stakeholders to enforce and encourage CG practices. Nevertheless, CG is evolving in Saudi Arabia and the country is also conscious of attracting investments especially foreign direct investments (FDI) in line with their vision 2020. The country's institutional environment may not be too close to those of OECD nations, but the establishment of the new 2006 CG code and as amended is a positive addition to the business culture and provides a platform upon which Saudi practitioners must operate.

\section{Saudi Arabia CG Regulations 2006 and as Amended}

The introduction of the 2006 code of CG for public companies is an attempt to improve CG practices in Saudi Arabia. This code has since been updated, but there is no real material difference between this code and the later versions. This was also the first attempt to comprehensively reform CG environment in the country (Al Mulhim, 2014).

In February 2006 the Saudi stock market failed, resulting in enormous loss to investors (Alshehri, 2012; Hill et al., 2015). Which financial observers, believed was as a consequence of lack of effective CG mechanisms and market infractions. To avoid a repeat occurrence of this episode and also to protect investors the regulatory authority issued what may seem the first comprehensive code of CG regulations in 2006 (Al Mulhim, 2014; Hill et al., 2015). The Saudi Arabia 2006 code of CG regulations was initially voluntary for all listed companies to abide with, but was later made compulsory in 2010 (Al-Janadi et al., 2016).

The CG regulation of 2006 was amended several times and was eventually reissued in 2017 and further amended by Resolution of the Board of the Capital Market Authority Number 3-45-2018. The regulations see CG as "rules to lead and guide the Company that includes mechanisms to regulate the various relationships between the Board, Executive Directors, shareholders and Stakeholders, by establishing rules and procedures to facilitate the decision making process and add transparency and credibility to it with the objective of protecting the rights of shareholders and Stakeholders and achieving fairness, competitiveness and transparency on the Exchange and the business environment" (The Saudi Arabia CG regulations, 2017. p. 7).

The Saudi Arabia CG regulations are divided into parts and articles. Some of the major provisions of the regulations are discussed below: "Part 2: The general rights of shareholders. It declares that shareholders are entitled to all Rights attached to their shares including: - Article 6: Shareholder access to information, Article 7: Communicating with Shareholders, Article 8: Electing the Board Members, Article 9: Distribution of Dividends" (The Saudi Arabia CG regulations, 2017. pp. 7-12). These are among other rights and privileges available to shareholders.

The CG regulations in part three of its provision talked about the Board of Directors (BOD).as follows; Articles 
16 and 17 are about BOD composition and appointments respectively. This Articles state specifically that "the majority of board Members shall not be company executives, and independent Directors shall constitute at least one third of the total number of directors" (The Saudi Arabia CG regulations, 2017. p. 7-12). Articles 18 and 19 are about qualification and termination respectively of members of the BOD. Article 22 highlights the main duties of the BOD. "Article 24 is prohibition of duality of the posts of chairman of BOD and CEO. While article 50; explains some general guidelines for board committees" (The Saudi Arabia CG regulations, 2017. p. 17-22)

Six articles $(54 ; 55 ; 56 ; 57 ; 58$ and 59) are for Audit Committee, this shows the importance attached to the committee. These articles specify the appointment, composition, qualifications and functions of the audit committee. The chairman of the committee shall be an independent director to guarantee the independence of the committee in the discharge of its functions.

There are several other more robust provisions in the Saudi Arabia CG regulations. Some of these provisions are in line with OECD standards. The question is why is CG practices still very weak in the country? Some of the reasons have been identified in the previous section (CG development in Saud Arabia). It is worth stating that insider dominated boards are common feature in Saudi Arabia corporate sector (Saidi, 2004). This brings to question, the 'true independence' of BOD. Research findings show that board independence can help reduce earning management practices by management (Cravens and Wallace, 2001; Peasnell et al., 2005; Gonza' lez and García-Meca, 2014).

This attempt to formally regulate the Saudi CG environment has at least created awareness among entities and stakeholders. The subsequent amendments have also to some extent partially addressed some of the defects in the earlier ones (Al-Bassam et al. 2018; Buallay et al. 2017). Nevertheless, there are other fundamental issues that are not in conformity with the international best practices; like those of OECD standards. To improve on the country's current CG reputation, the CMA should address these identified issues.

\section{Review of Literature and Findings on Corporate Governance Structures in Saudi Arabia}

Previous studies have used several CG determinants; either individually or combination of determinants to measure how effective a CG system is. A good number of studies however, would like to use a combined measurement; composed of various variables (corporate diversification level, ownership concentration, disclosure quality) to measure the degree of good CG (Mitton, 2002). For example, Gompers et al. (2003) have combined various determinants to create governance index 'G- score', to measure the overall extent of corporate governance of companies.

Researchers on the development of CG in Saudi Arabia have also developed various measures or determinants to assess the state of CG in the country. The findings of such studies are mixed and making some researchers to recommend a general review and update of the Saudi CG regulations. Their argument has always been the inability of the regulatory authority to develop a comprehensive strategy for CG practices in the country. Nevertheless, observers of Saudi Arabia's CG system believe to some extent that the country has made relative progress with respect to the implementation of viable and culturally appropriate governance mechanisms (Al-Bassam et al. 2018). Though, effectiveness of some of the CG structures in the Kingdom is inadequate, so also is the CG framework which relies on the principles of responsibility, fairness, transparency and accountability very weak (Al-Ghamdi \& Rhodes, 2015).

The agency problem and its resultant conflict of interest arose as a result of separation of ownership from control. Sound CG system has been identified as likely solution to this phenomenon. Among the determinants identified in literature is the audit committee (AC). Audit committee is an essential element of corporate governance (Green, 1994). The AC role among others is to reduce information asymmetry between stakeholders and managers and therefore, mitigates agency problems.

In line with this perceived role of the AC, Al-Matari et al. (2012) using companies listed on the Saudi stock exchange tried to establish if there is relationship between the internal corporate governance Mechanisms related to $\mathrm{AC}$ characteristics and corporate performance. The study specifically stated that $\mathrm{AC}$ independence and number meetings do not add value to firm performance. This is contrary to agency theory assumption that AC might mitigate agency problems leading to reduced agency cost by aligning the interests of the principal and the agent, which might impact on company bottom-line by way of reduced agency cost. The authors therefore, recommended that the authority should review the role of the committee specifically in the areas of composition and independence to enhance their competence.

Al-Janadi et al. (2013) in their study used a combined measurement composed of various CG variables or determinants to measure the degree of CG effectiveness. The study this time measured the effectiveness of both 
internal and external CG determinants on corporate voluntary disclosure (VD) of 87 listed companies in Saudi Arabia stock exchange. The study turned out relatively positive results as most of the CG variables (e.g. Independent directors on the board, government ownership CEO duality and audit quality) have a significantly positive effect on corporate VD in the study. But they specifically noted that, despite 94 per cent of the audit committee members being 'independent', they were not effective in providing quality reports. They therefore, questioned how truly 'independent' the audit committee members are? Thus, recommended that the Stock market regulators should review the guidelines, especially as it relates to the mode of their appointment to enable them play effective roles.

In a similar study by Al-janadi et al. (2016), but this time using Government ownership (GO) as moderating effect on CG and VD. The findings show that companies without government control tend to perform better in adopting good CG practices resulting in sufficient and quality disclosures.

Al-Moataz and Hussainey (2013) used content analysis approach to analyze a sample of 97 financial reports and accounts of listed companies on the Saudi stock exchange for the period 2006 to 2007. The findings show that audit committee size is the main determinant of CG disclosure in Saudi Arabia. Board size and board independence do not have significant impact on the level of CG voluntary disclosure. The lack of corporate board's independence as a result of ownership structure has always been a concern militating against the development of CG not only in Saudi Arabia but in most emerging economies. According to Barako et al. (2006), most outside or independent directors in developing countries are not truly independent.

Using a weighted index of CG characteristics on company performance and value of Saudi-listed companies, Fallatah and Dickins (2012) found that CG and company performance (measured as return on assets) are unrelated, but CG and firm value (measured as Tobin's Q and market value of equity) are positively related. They noted among other things that in Saudi Arabia equity financing is more closely held; that is shares are held by few individuals. More emphasis is place on ownership of equity shares than comparative performance and CG. This perception may hinder CG development and limit investments, especially foreign direct investment, as external investors may attribute higher values to companies with strong corporate governance.

Buallay et al. (2017) examined the impact of CG on Firm performance using pooled data collected from sample of 171 listed companies on the Saudi stock exchange. Generally, this study gave a better ranking for CG development in Saudi Arabia. The study found that the governance level was $61.4 \%$ in listed companies which is considered high compared to previous studies. Specifically, the study noted that the adoption of CG principles have not significantly impacted on companies' operational and financial performance. A second finding also shows that large share ownership and board independence do not affect companies' market performance. Nevertheless, the study identified board size as a factor affecting companies' performance. Finally, the study recommended that the Capital Market Authority should pay more attention to ownership concentration in the Saudi listed companies to avoid or limit the excesses of controlling shareholders.

The extent to which Saudi listed companies voluntarily comply with and disclose recommended good CG practices was also tested by Al-Bassam et al. (2018). The study identified companies audited by the Big-4 auditors; companies where government has controlling shares, institutional ownership and those with larger boards. The study's results suggest that corporations with larger boards, a Big 4 auditor, higher government ownership and higher institutional ownership are more compliant in terms of disclosure of recommended good CG practices. The study noted evidence of increasing compliance with the Saudi CG Code as a result of efforts by various stakeholders, notably the CMA and Saudi Stock Exchange at improving CG standards in Saudi corporations. For the large differences in the levels of compliance among Saudi Arabia corporations, the study recommended the establishment of a "compliance and enforcement committee" to continuously monitor compliance levels among listed companies.

Al-Ghamdi and Rhodes (2015) also examined CG and performance of companies listed on the Saudi Stock Exchange. Their study covered the eleven major industrial sectors for a period of eight years $(2006-2013)$. Their major focus was on Family and Non-family controlled companies using two (ROA and Tobin's Q) performance measurement indices. Their findings show that ownership concentration does not influence firm performance when using ROA as a measure. But the result showed a significantly positive relationship with Tobin's Q measure. Their findings also indicated that managerial ownership in family companies has a positive relationship when either of the performance indicators was used but not so with non-family companies. These results generally indicate that ownership concentration is still an issue to be contending with in CG development in Saudi Arabia.

The effect of some CG mechanisms on financing decisions in Saudi Arabian listed Companies was investigated 
by Al-Nodel and Hussainey (2010). They focused principally on three CG determinants: CG reporting or disclosure, ownership concentration and corporate board size on the debt-to-equity ratio. CG reporting or disclosure has no significant relationship with debt-to-equity ratio according to their finding. The simple implication is that company information whether quarterly or annually is not an important driver of the financing decision of Saudi Arabian companies. According to the authors "This finding is affected by the characteristics of Saudi society where the impact of personality and power of particular individuals, the role of family and friend relationships prevail over regulations, and tasks, and the existence of a high level of secrecy" (Al-Nodel and Hussainey, 2010, p. 12).

Global CG standards were endorsed by OECD ministers in 1999; this is part of an attempt to direct and influence policymakers worldwide to adapt these common CG standards. The adoption and success of these standards outside the OECD member countries is still unclear. Robertson et al. (2012) analyzed the perceptions of Western CG principles in Saudi Arabia. The level of perception was gauged by using a survey instrument developed by them on about 168 Saudi Arabian corporate managers.

Their findings suggest that managers' perception indicate that effective CG framework relatively exist especially for shareholders' rights. Perceptions of shareholder rights are positively related to maintaining an effective corporate CG framework. In other words; there is a level of appreciation by Saudi corporate managers of the link between the rights of shareholders and the importance that governance mechanisms play in monitoring of management by the board of directors. Finally, the study opined that "The CMA guidelines in Saudi Arabia are country-specific yet have conceptual foundation that stretches beyond the borders of Saudi Arabia" (Robertson et al. 2012. P. 408). But "yet the extent to which incorporating local contextual and cultural issues into a viable governance framework can be extraordinarily country-specific and many local institutions may choose to embrace deeply seated and highly revered traditions" (p.408).

Recently, Alzeban (2019) explored the impact of internal audit (IA) compliance with the International Standards for the Professional Practice of Internal Auditing (ISPPIA) on financial reporting quality (FRQ). These ISPPIA regulations are to assist in the improvement of CG practices. The target participants were 142 chief audit executives from Saudi Arabia listed companies, and relevant information were also extracted from the annual reports of the participating companies. Discretionary accruals and accruals quality were used as proxies. The study concluded that companies that have IA departments that are modeled in line with ISPPIA guidelines and also higher IA standards compliant have better FRQ.

Previous studies have established link between CG and earnings quality. According to Claessens and Yurtoglu (2013); the lack of efficient CG mechanisms triggers this managerial opportunistic behavior which is exemplified in earnings management. Habbash and Alghamdi (2016) empirically examine the relationship between earnings management and audit quality attributes (auditor size, auditor industry specialization, auditor opinion, auditor change and timeliness of auditor report) using a sample of 137 non-financial Saudi listed firms for the period 2006-2009.

Their findings indicate that of all the variables used in the study only the auditor opinion variable is able to constrain earnings management practice in the context of Saudi Arabia. These findings support the view by Becker et al. (1998), that auditors' ability to effectively reduced managerial opportunistic behavior is limited because of their heavy reliance on the client revenue. In their opinion to address this issue the Saudi professional accounting body (SOCPA) should ensure and encourage more professional accounting development in order to enhance the auditor's independence and competence.

Several other studies have also explored the Saudi Arabia CG environment; Habbash (2015) reviewed the corporate social responsibility (CSR) disclosure practices and the potential influence of CG; ownership structure and corporate characteristics in Saudi Arabia. The period span from 2007 to 2011using manual content and multiple regression analyses against a checklist of 17 CSR disclosure items based on ISO 26000. Generally, the study showed relative improvement in CSR disclosure partly as a result of the Saudi CG code of 2006. The CG variables showed different levels of influence to no influence on CSR disclosure.

CG has been identified to play a crucial role even in times of financial crisis. Ezzine (2018) examine the effectiveness of CG determinants and resistance to financial crisis and compliance with social norms. Specifically, the study focused on differences between French and Saudi firms during the financial volatility (subprime crisis) of 2007. The findings indicate that independent members on boards, larger audit committee members and larger boards are negatively related to financial volatility, but noted that compliance with CSR alone does not explain the financial volatility, but should be in concert with other CG variables. 
Marai et al. (2017) specifically examined the Saudi corporate CG code, and to assess its effectiveness, using annual financial reports for the period from 2007 to 2014. The main findings show that the provisions of Saudi CG code are adequate to address CG issues and a relative increase in compliance level for the period studied. But its impact on company's performance and addressing earnings management is limited. The study traced the inability of the code to address these two vital issues to some economic, social and cultural factors, and weak legal enforcement. In a similar study conducted by Al-Thuneibat et al. (2016), but this time using discretionary accruals (DA) as a proxy for earnings management. The study finds no statistically significant relationship between CG and DA. Specifically the study finds no statistically significant effect of CG determinants like; internal audit, audit committee and board of directors on earnings management. The study therefore, urged regulatory authorities to have a second look at the CG regulations especially in the areas of enforcement.

\section{Methodology}

In line with L'Huillier (2014) we conducted a guided words search on electronic databases using "corporate governance in Saudi Arabia" as the search words. The scope of the study was restricted to the needed materials and information contained in refereed journals dating back to 2018 and held in the ABI/INFORM Global, Emerald databases and a few other internationally recognized databases. Priority in the selection of articles was given to most current studies unless where an article gives a comprehensive historical perspective of the subject matter, as the more specific the topic or question being searched is, the more focused the result will be

The content analysis approach is the main methodology of this study. The identified academic publications were then discussed, and their findings analyzed. A review of the articles revealed that about $80 \%$ of the academic publications on CG in Saudi Arabia are centered on company financial performance, while the remaining $20 \%$ are focused on other areas.

\section{Discussion and Conclusion}

This study reviewed the academic literature on the study and development of CG in Saudi Arabia. In addition to reviewing the literature we also examined the question of how the CG mechanisms are really enforced given the institutionally weak context of Saudi Arabia. A general review of published works on Saudi Arabia's CG system revealed that about six broad areas have been examined in relation to CG structures; they include: company financial performance, corporate social responsibilities, earnings management, corporate voluntary disclosures, financial structure and even the role of CG in times of financial crisis. The evidence provided by the literature review is clearly weighted in favour of studies on CG and company financial performance; more than $80 \%$ is devoted to this area.

Corporate governance has evolved in Saudi Arabia; starting from the company law of 1965 to the Saudi's Corporate Governance Regulations of 2006 that was subsequently amended in April, 2018. Some observers of Saudi Arabia's CG system also believe to some extent that the country has made relative progress, especially in CG structures with cultural colorations that support the human resource management function with respect to the implementation of viable and culturally appropriate governance mechanisms. These CG related human resource structures and functions are truly powered by the country's 'Saudinization agenda' (gradual replacement of expatriate workers with Saudi citizens). Yet, from a Western governance perspective especially OECD standards some components of a comprehensive governance strategy have not been fully integrated into the Saudi CG system. The effectiveness of some of the CG structures in the Kingdom is inadequate, so also is the CG framework which relies on the principles of responsibility, fairness, transparency and accountability very weak.

The country's institutional environment may not be too close to those of OECD nations, but the establishment of the new 2006 CG code and as amended is a positive addition to the business culture and provides a platform upon which Saudi authorities and business practitioners must operate. Nevertheless, there are still other outstanding CG issues identified by scholars and practitioners that are not in conformity with the international best practices. Therefore, to improve on the country's current CG reputation, the CMA the main regulator of the country's business environment should address these identified issues, particularly the concentrated ownership structures of companies in the country.

These findings and final observations are to some extent also applicable to other developing economies, particularly Gulf corporation council (GCC) countries as they share common cultural and corporate features; especially in ownership and management structures.

This study makes a new contribution to the CG literature by providing a comprehensive review and analysis of CG development and practice in an emerging economy where greater importance is usually attached to informal relationships and other considerations than formal CG mechanisms. The man limitation of this study is that, 
analysis was restricted to between 1965 and 2018, and papers from some and not all electronic data bases were used, subsequent studies should consider a larger data base and extend the study period. Acknowledging the fact that studies on this dynamic and topical issue of CG is mainly carried out in developed economies; further studies on developing countries are required with emphasis on theoretical construct and the reasons for its relatively very poor performance.

\section{References}

Agrawal, A., \& Chadha, S. (2005). Corporate governance and accounting scandals. Journal of Law and Economics, 48(2), 371-406.

Al Mulhim, A. B. (2014). An investigation into the relationship between corporate governance and firm performance in Saudi Arabia after the reforms of 2006, Ph.D. Thesis, University of London.

Al- Thuneibat, A., Al-Angari, H., \& Al- Saad, S. (2016). The effect of corporate governance mechanisms on earnings management. Review of International Business and Strategy, 26, 2-32.

Al-Bassam, W. M., Ntim2, C. G., Oponb, K. K., \& Downs, Y. (2018). Corporate Boards and ownership structure as antecedents of corporate governance disclosure in Saudi Arabian publicly listed corporations. Business \& Society, 57(2), 335-337.

Al-Ghamdi, M., \& Rhodes, M. (2015). Family ownership, corporate governance and performance: evidence from Saudi Arabia. International Journal of Economics and Finance, 7(2), 78-89. https://doi.org/10.5539/ijef.v7n2p78

Al-Janadi, Y., Rahman, R. A., \& Alazzani, A. (2016). Does government ownership affect corporate governance and corporate disclosure? Managerial Auditing Journal, 31(9), 871-890 https://doi.org/10.1108/MAJ-12-2015-1287

Al-Janadi, Y., Rahman, R. A., \& Omar, N. H. (2013). Corporate governance mechanisms and voluntary disclosure in Saudi Arabia. Research Journal of Finance and Accounting, 4(4), 25-36.

Al-Malkawi, H. A. N., Pillai, R., \& Bhatti, M. (2014). Corporate governance practices in emerging markets: The case of GCC countries. Economic Modelling, 38, 133-141.

Al-Matari, Y. A., Al-Swidi, A. K., Fadzil, F. H. B., Fadzil, H., \& Al-Matari, E. M. (2012). Board of Directors, Audit Committee Characteristics and the Performance of Saudi Arabia Listed Companies. International Review of Management and Marketing, 2(4), 241-253.

Al-Moataz, E., \& Hussainey, K. (2013). Determinants of corporate governance disclosure in Saudi Arabia. Journal of Economics and Management, 27, 411-430.

Al-Nodel, A., \& Hussainey, K. (2010). Corporate governance and financing decisions by Saudi companies. Journal of Modern Accounting and Auditing, 6, 1-14.

Alshehri, A., \& Solomon, J. F. (2012). The evolution of corporate governance in Saudi Arabia. British Accounting and Finance Association (BAFA) 2012. Conference Paper, Brighton, UK.

Al-Twaijry, M., Brierley, A., \& Gwilliam, R. (2002). An examination of the role of audit committees in the Saudi Arabian corporate sector. Corporate Governance: An International Review, 10, 288-297.

Alzeban, Z. (2019). An examination of the impact of compliance with internal audit standards on financial reporting quality: Evidence from Saudi Arabia. Journal of Financial Reporting and Accounting, 17(3), 498-518.

Barako, D. G., Hancock, P., \& Izan, H. (2006). Factors influencing voluntary corporate disclosure by Kenyan companies. Corporate Governance: An International Review, 4, 107-125.

Becker, C., Defond, M., Jiambalvo, J., \& Subramanyam, K. (1998). The effect of audit quality on earnings management. Contemporary Accounting Research, 15(1), 1-24.

Bonnafous-Bucher, M. (2005). Some philosophical issues in corporate governance: the role of property in stakeholder theory. Corporate Governance, 5(2), 34-47.

Buallay, A., Hamdan, A., \& Zureigat, Q. (2017). Corporate governance and firm performance: evidence from Saudi Arabia. Australasian Accounting, Business and Finance Journal, 11(1), 78-98.

Claessens, S., \& Yurtoglu, B. (2013). Corporate governance in emerging markets: A survey. Emerging Markets Review, 15, 1-33. 
Classens, S. (2003). Corporate governance and development, focus 1. Global Corporate Governance Forum, World Bank, Washington.

Cohen, J., Krishnamoorthy, G., \& Wright, A. (2002). Corporate governance and the audit Process. Contemporary Accounting Research, 19, 573-594.

Cohen, J., Krishnamoorthy, G., \& Wright, A. (2004). The corporate governance mosaic and financial reporting quality. Journal of Accounting Literature, 23, 87-152.

Cravens, K., \& Wallace, W. (2001). A Framework for Determining the Influence of the Corporate Board of Directors in Accounting Studies. Corporate Governance: An International Review, 9(1), 2-24.

Darus, F. (2011). Corporate governance and corporate failure in the context of agency theory. The Journal of American Academy of Business, 17(1), 125-132.

Donaldson, L., \& Davis, J. H. (1991). Stewardship theory or agency theory: CEO governance and shareholder returns. Australian Journal of Management, 16(1), 49-64.

Donaldson, T., \& Preston, L. E. (1995). The stakeholder theory of the corporation: concepts and evidence. Academy of Management, 20(1), 65-81.

Evan, W. M., \& Freeman, R. E. (1988). A stakeholder theory of the modern corporation: Kantian capitalism. cited in Donaldson, T. and Preston, L. E. (Eds.), The stakeholder theory of the corporation: concepts and evidence.

Ezzine, H. (2018). Corporate governance and social norms during financial crisis: evidence from France and Saudi Arabia. Journal of Management and Governance, 22, 707-748.

Fallatah, Y., \& Dickins, D. (2012). Corporate governance and firm performance and value in Saudi Arabia. African Journal of Business Management, 6(36), 10025-10034. https://doi.org/10.5897/AJBM12.008

Gillibrand, M. (2004). Corporate management essential for industrialization. The Bangladesh Observer.

Gompers, P., Ishii, J., \& Metrick, A. (2003). Corporate Governance and Equity Prices. The Quarterly Journal of Economics, 118(1), 107-155.

Gonza' lez, S., \& Garcı' a-Meca, E. (2014). Does Corporate Governance Influence Earnings Management in Latin American Markets? Journal of Busness Ethcs, 121, 419-440.

Green, D. (1994). Canadian audit committees and their contribution to corporate governance. Journal of International Accounting, Auditing and Taxation, 3(2), 135-151.

Habbash, M. (2015). Corporate governance, ownership, company structure and environmental disclosure: Evidence from Saudi Arabia. Journal of Governance and Regulation, 4(4), 460-470.

Habbash, M., \& Alghamdi, S. (2016). Audit quality and earnings management in less developed economies: the case of Saudi Arabia. Journal of Management and Governance, 21(2), 351-373.

Heath, J., \& Norman, W. (2004). Stakeholder theory, corporate governance and public management: what can the history of state-run enterprises teach us in the post-enron era? Journal of Business Ethics, 53(1), $247-265$

Hill, B., Lunn, M., Morrison, W., Mueller, J., \& Robertson, C. (2015). Saudi Arabia: an overview of executive compensation, board structure, and sustainability. Drake Management Review, 4(1/2), 20-33.

Hung, H. (1998). A typology of the theories of the roles of governing boards. Corporate Governance Scholarly Research and Theory Papers, 6(2), 101-111.

L'Huillier, B. M. (2014). What does corporate governance mean. Corporate Governance, 14(3), 308-319.

La Porta, R., Lopez-de-Silanes, F., \& Shleifer, A. (1999). Corporate Ownership Around the World. The Journal of Finance, 2, 471-517.

Marai, A., Elghariani, O., \& Pavlović, V. (2017). Practice and effectiveness of internal corporate governance mechanisms in Saudi Arabia stock market: A review of empirical evidence. Megatrend Revija, 14(1), 63-82. https://doi.org/10.5937/megrev1701063m

Mason, C., Kirkbride, J., \& Bryde, D. (2007). From stakeholders to institutions: the changing face of social enterprise governance theory. Management Decision, 45(2), 284-301.

Merino, B. D., Mayper, A. G., \& Tolleson, T. D. (2010). Neoliberalism, deregulation and Sarbanes-Oxley: the legitimation of a failed corporate governance model. Accounting, Auditing and Accountability Journal, 
23(6), 774-792.

Meteb, A. M. (2015). The importance of corporate governance in Saudi Arabia economy. Journal of WEI Business and Economics, 4(1), 14-27.

Mitton., T. (2002). A cross-firm analysis of the impact of corporate governance on the East Asian financial Crisis. Journal of Financial Economics, 64(2), 215-241.

Mujtaba, N., \& Williams, A. (2011). Corporate Governance and Board Composition: A comparison of GCC boards with UK, European and US boards. Report issued by corporate governance consultants. Manama, Bahrain.

O’Donovan. G. (2003). Change Management - A Board Culture of Corporate Governance. Mondaq Business Briefing.

Organization for Economic Co-Operation and Development (1999). OECD Principles of Corporate Governance. OECD, Paris, France.

Peasnell, K. V., Pope, P. F., \& Young, S. E. (2005). Board monitoring and earnings management: do outside directors influence abnormal accruals? Journal of Business Finance \&Accounting, 32(7-8), 1311-1346.

Robertson, C., AL-Asheikh, S., \& Al-Kahtani, A. (2012). An nalysis of perceptions of Western corporate governance. International Journal of Public Administration, 35(6), 402-409. https://doi.org/10.1080/01900692.2012.655529

Saidi, N. (2004). Corporate governance in MENA countries: improving transparency and disclosure. The Second Middle East and North Africa Regional Corporate governance forum. Beirut, June. 3-5.

Samaduzzaman, M., Zaman, F., \& Quazi, Z. (2015). Literature Review on Corporate Governance Structure and Performance in Non-Financial Firms in Bangladesh. Asian Journal of Finance \& Accounting, 7(1), 96-104.

Saudi Arabian Capital Market Authority (SACMA), (2006). Criteria of the best practices of corporate governance. Retrieved from http://www.cma.org.sa/cma\%5Far/

Saudi Arabian Capital Market Authority (SACMA). (2017). The Saudi Arabia CG regulations, Retrieved from https://cma.org.sa/en/RulesRegulations/Regulations/Documents/CGRegulations_en.pdf

Shleifer, A., \& Vishny, R. (1997). A Survey of Corporate Governance. Journal of Finance, 52(2), 737-783.

Short, H., Keasey, K., Wright, M., \& Hull, A. (1999). Corporate governance: from accountability to enterprise. Accounting and Business Research, 29(4), 337-352.

Stein, M. (2008). Beyond the boardroom: government perspectives on corporate governance. Accounting, Auditing and Accountability Journal, 21(7), 1001-1025.

Sternberg, E. (1998). Corporate governance: accountability in the marketplace. Hobart Paper 137, The Institute of Economic Affairs, Westminster, London.

Stiles, P. (1997). London business school. cited in Clarke, T. (1998), Research on Corporate Governance Reports. Corporate Governance, 6(1), 57-97

Wright, M., Hoskisson, R., Filatotchev, I., \& Peng, M. (2005). Strategy Research in Emerging Economies: Challenging the Conventional Wisdom. Journal of Management Studies, 42(1), 1-33 https://doi.org/10.1111/j.1467-6486.2005.00487.x

Yasin, H., \& Shehab, I. (2004). Monitoring and Overseeing Disclosure. Presented in the Corporate Governance in MENA Countries: Improving Transparency and Disclosure, the Second Middle East and North Africa Regional Corporate Governace Fourm, Beirut.

\section{Copyrights}

Copyright for this article is retained by the author(s), with first publication rights granted to the journal.

This is an open-access article distributed under the terms and conditions of the Creative Commons Attribution license (http://creativecommons.org/licenses/by/4.0/). 